case ventilatory depression returns. The use of a larger dose of naloxone, given either intravenously or intramuscularly, is being investigated to determine whether the action of naloxone can be usefully prolonged.

We thank the midwives, obstetricians, and paediatricians of the University Hospital of Wales for their help and co-operation in the study.

\section{References}

${ }^{1}$ Koch, G, and Wendel, H, Acta Obstetrica et Gynecologica Scandanavica, $1968,47,27$.

2 Evans, J M, et al, British Medical fournal, 1974, 2, 589.

3 Evans, J M, et al, Anaesthesia, 1974, 29, 721.

4 Evans, J M, Hogg, M I J, and Rosen, M, British fournal of Anaesthesia, in press.

5 Siegel, S, Non-parametric Statistics, (International Student Edition). Tokyo, McGraw-Hill Kogakusha Ltd, 1965.

\title{
Streptokinase in acute myocardial infarction: a controlled multicentre study in the United Kingdom
}

\author{
C P ABER, N M BASS, C L BERRY, P H M CARSON, R J DOBBS, K M FOX, J J HAMBLIN, \\ S P HAYDU, G HOWITT, J E MACIVER, R W PORTAL, E B RAFTERY, R H ROUSELL, \\ J P P STOCK
}

British Medical fournal, 1976, 2, 1100-1104

\section{Summary \\ In a multicentre trial of streptokinase in acute myocardial infarction 302 patients received an intravenous infusion of 2500000 IU of streptokinase over 24 hours, while 293 patients served as controls. Neither group received anticoagulants unless indicated by thromboembolic complications. No significant difference in mortality was evident during inpatient treatment nor at six-week or six-month follow-up. The inpatient death rate was $12.6 \%$ in the streptokinase group and $13.7 \%$ among controls.}

There was no significant difference in the peak levels or pattern of enzyme increase. The incidence of cardiac failure and reinfarction was similar in the two groups, but major arrhythmias were less common in those on streptokinase $(P<0.05)$. In the streptokinase group there were 36 minor and six more serious haemorrhagic com-

Kingston General Hospital, Kingston-upon-Hull

C P ABER, MD, FRCP, consultant cardiologist

$\mathrm{K} M \mathrm{FOX}, \mathrm{MB}, \mathrm{MRCP}$, registrar in cardiology

R W PORTAL, MD, FRCP, consultant cardiologist

Stoke-on-Trent

N M BASS, MB, MRCP, honorary senior registrar (present address : Cardiology

Department, Green Lane Hospital, Auckland, New Zealand)

P H M CARSON, FRCP, FACC, consultant cardiologist

J P P STOCK, MD, FRCP, consultant cardiologist (Dr Stock died on 4 October 1973)

Guy's Hospital Medical School, London

C L BERRY, MD, MRCPATH, reader in pathology

Manchester Royal Infirmary, Manchester

R J DOBBS, MRCP, DHC, research fellow, cardiology department

G HOWITT, MD, FRCP, consultant cardiologist

J E MACIVER, MD, FRCPATH, consultant haematologist

Southend General Hospital, Westcliff-on-Sea, Essex

J J HAMBLIN, MB, MRCP, consultant physician

$S$ P HAYDU, MB, MRCP, registrar

Northwick Park Hospital, Harrow, Middlesex

E B RAFTERY, MD, MRCP, consultant cardiologist

Hoechst Pharmaceuticals, Hounslow, Middlesex

R H ROUSELL, MSC, MB, head of medical services plications. Gastrointestinal haemorrhage may have contributed to the death of one patient in each group. There were 18 thromboembolic complications in the streptokinase group and 38 among the controls. Pathological examination of the hearts of 25 patients who had taken streptokinase and 24 controls showed no striking differences between the groups, but haemorrhagic infarcts were found in three patients who had received streptokinase.

An infusion of streptokinase within 24 hours of the onset of acute myocardial infarction does not significantly affect the mortality or course of the illness up to six months.

\section{Introduction}

Since the introduction of streptokinase into clinical practice 17 years ago $^{12}$ the therapeutic value of thrombolytic agents in acute myocardial infarction has remained in doubt. Only recently have a series of major controlled trials been undertaken (table I).$^{3-7}$ No conclusive result in favour of streptokinase has emerged from these studies, in which the initial thrombolytic treatment followed by anticoagulation was compared with anticoagulant treatment alone. The trial reported here was started in the United Kingdom in August 1971 and ended in June 1974. Its object was to determine whether thrombolytic treatment influenced early or late mortality, the incidence of complications, and the pathological findings in the hearts of patients who died. Preliminary results have been briefly reported $^{8}$; we present here the final results, concluding the study at six months' follow-up.

\section{Design of trial}

Criteria for admission-The trial was conducted in coronary care units in five different hospitals, the only requisite for entry being a diagnosis of myocardial infarction within the previous 24 hours. At the time of entry into the trial this rested necessarily on the clinical picture and the initial electrocardiogram (ECG). The ECG criteria for infarction used were those of the World Health Organisation, ${ }^{9}$ the diagnosis of acute infarction was not accepted unless there was a significant increase in either serum aspartate aminotransferase (SGOT) or lactate dehydrogenase (LDH) concentrations, or both. Both sexes were accepted and no upper age limit was prescribed.

Statistical design-The statistical design, described by Armitage, ${ }^{10}$ tested the null hypothesis that the death rates in the streptokinase and control groups were the same against a two-sided alternative 
TABLE I-Details of major controlled trials of streptokinase treatment in myocardial infarction

\begin{tabular}{|c|c|c|c|c|c|c|c|c|c|c|c|}
\hline \multirow{2}{*}{ Trial } & \multirow{2}{*}{ Year } & \multirow{2}{*}{$\begin{array}{c}\text { No of } \\
\text { patients }\end{array}$} & \multirow{2}{*}{$\begin{array}{c}\text { Anticoagulants } \\
\text { used in control } \\
\text { and streptokinase } \\
\text { groups }\end{array}$} & \multicolumn{2}{|c|}{$\begin{array}{l}\text { Streptokinase } \\
\text { dose (IU) }\end{array}$} & \multirow{2}{*}{$\begin{array}{l}\text { Duration } \\
\text { of } \\
\text { infusion } \\
\text { (hours) }\end{array}$} & \multirow{2}{*}{$\begin{array}{l}\text { Interval between } \\
\text { onset of } \\
\text { symptoms and } \\
\text { start of } \\
\text { treatment } \\
\text { (hours) }\end{array}$} & \multicolumn{3}{|c|}{ Mortality (\%) } & \multirow{2}{*}{$\begin{array}{l}\text { Significance } \\
(\mathrm{P})\end{array}$} \\
\hline & & & & Loading & Hourly & & & Time period & $\begin{array}{l}\text { strepto- } \\
\text { kinase }\end{array}$ & Controls & \\
\hline German/Swiss $I^{4}$ & 1966 & $558^{*}$ & Yes & 250000 & 150000 & 18 & $<12$ & $\begin{array}{l}\text { Up to } 40 \text { days } \\
\leqslant 24 \text { hours } \\
2-40 \text { days }\end{array}$ & $\begin{array}{r}14 \cdot 1 \\
5 \cdot 4 \\
8 \cdot 7\end{array}$ & $\begin{array}{r}21 \cdot 7 \\
5 \cdot 4 \\
16 \cdot 1\end{array}$ & $\begin{array}{l}<0.05 \\
\text { NS } \\
<0.02\end{array}$ \\
\hline German/Swiss II $^{5}$ & 1970 & $269^{*}$ & Yes & 250000 & 100000 & 18 & $<12$ & $\begin{array}{l}\text { Up to } 40 \text { days } \\
224 \text { hours }\end{array}$ & $\begin{array}{r}14 \cdot 5 \\
2 \cdot 2 \\
12 \cdot 3\end{array}$ & $\begin{array}{l}26 \cdot 0 \\
10 \cdot 7 \\
15 \cdot 3\end{array}$ & $\begin{array}{l}<0.03 \\
<0.01 \\
\mathrm{NS}\end{array}$ \\
\hline $\begin{array}{l}\text { European Working } \\
\text { Party }^{6}\end{array}$ & 1971 & $730 \dagger$ & Yes & 250000 & 100000 & 24 & $<24$ & $\begin{array}{l}\text { Up to discharge } \\
\leqslant 24 \text { hours } \\
2 \text { days to } \\
\text { discharge }\end{array}$ & $\begin{array}{r}18.5 \\
8 \cdot 8 \\
10 \cdot 6\end{array}$ & $\begin{array}{l}26 \cdot 3 \\
10 \cdot 4 \\
17 \cdot 8\end{array}$ & $\begin{array}{l}<0.02 \\
\text { NS } \\
<0.02\end{array}$ \\
\hline Italy ${ }^{7}$ & 1971 & $\left(\begin{array}{c}321 \dagger \\
(\mathrm{CCU})\end{array}\right.$ & Yes & 250000 & 150000 & 12 & $<12$ & $\begin{array}{l}\text { Up to } 40 \text { days } \\
\leqslant 24 \text { hours } \\
2-40 \text { days }\end{array}$ & $\begin{array}{r}11.6 \\
1.8 \\
9.9\end{array}$ & $\begin{array}{r}11 \cdot 5 \\
2 \cdot 6 \\
9 \cdot 1\end{array}$ & $\begin{array}{l}\text { NS } \\
\text { NS } \\
\text { NS }\end{array}$ \\
\hline Australia $^{8}$ & 1973 & $\left(\begin{array}{l}517^{+} \\
(\mathrm{CCU})\end{array}\right.$ & Yes & 250000 & 100000 & 17 & $<24$ & $\begin{array}{l}\text { Before } \\
\text { discharge } \S\end{array}$ & $6 \cdot 4$ & $8 \cdot 7$ & NS \\
\hline United Kingdom & 1975 & $\begin{array}{l}\text { (CCU }^{*} \\
\text { (CU) }\end{array}$ & No & 250000 & 100000 & 24 & $<24$ & $\begin{array}{l}\text { At } 3 \text { months } \\
\text { Up to } 42 \text { days } \\
\leqslant 24 \text { hours } \\
2-42 \text { days }\end{array}$ & $\begin{array}{r}9 \cdot 8 \\
14 \cdot 2 \\
3 \cdot 6 \\
11 \cdot 0\end{array}$ & $\begin{array}{r}12 \cdot 6 \\
15 \cdot 0 \\
4 \cdot 8 \\
10 \cdot 8\end{array}$ & $\begin{array}{l}\text { NS } \\
\text { NS } \\
\text { NS } \\
\text { NS }\end{array}$ \\
\hline
\end{tabular}

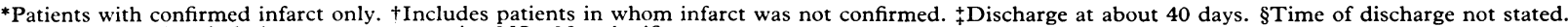
$\mathrm{CCU}=$ Conducted entirely in coronary care units. NS $=$ Not significant.

TABLE II-Prognostic Index (modified from Norris et al ${ }^{10}$ ) using patient's age and systolic blood pressure on admission

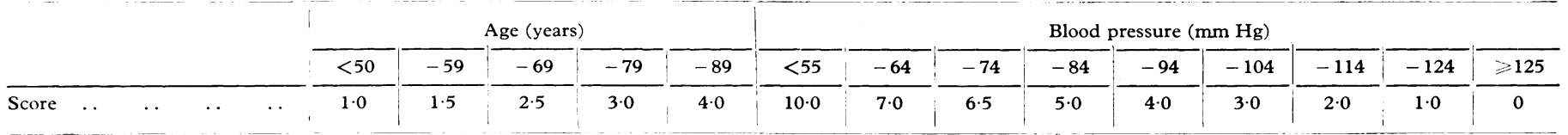

Subgroup 1-those with scores of $\leqslant 3$ (461 patients). Subgroup 2-those with scores of 3.5-8.5 (125 patients). Subgroup 3-those with scores of $\geq 9$ (9 patients).

hypothesis that one regimen would produce a higher death rate than the other. The chance of rejecting a true null hypothesis (type I error) was fixed at 0.025 and the chance of rejecting a true alternative hypothesis at 0.05 . In other words, a two-sided significance level of $21 \%$ with a power of $95 \%$ was used.

Exclusions-The chief reasons for exclusion from the trial were: known haemorrhagic disorder; gastrointestinal haemorrhage within the previous six months; history of peptic ulceration; recent surgery; an initial diastolic blood pressure over $120 \mathrm{~mm} \mathrm{Hg}$ or definite history of hypertension; hepatic disease; previous streptokinase treatment or previous entry to the trial.

Allocation and subgrouping-A total of 660 patients were admitted to the trial. The numbers contributed by the five participating centres ranged from 69 to 204. After admission to the trial the patient was allocated to one of three subgroups $(\mathrm{A}, \mathrm{B}$, or $\mathrm{C})$ according to a simple prognostic index modified from Norris et al ${ }^{11}$ (table II). This index was based on the sum of scores allocated according to the patient's age and systolic blood pressure on admission. Group C contained patients thought to be at greatest risk by virtue of their greatest age and lowest blood pressure. This stratification into three prognostic subgroups was not part of the statistical design, but was done only to ensure that the rarer patients with an initially greater chance of dying as a result of their infarction were divided evenly between the streptokinase and control groups. Each patient was then randomly allocated to either the streptokinase (332) or control (328) group.

Treatment regimen-Streptokinase 250000 IU was given in $25 \mathrm{ml}$ of $5 \%$ dextrose by intravenous infusion over 30 minutes. In the succeeding seven and a half hours a continuous infusion of 750000 units was given in a volume of $200 \mathrm{ml}$, followed by $750000 \mathrm{IU}$ in each of two further eight-hour periods. Thus a total of 2500000 IU was given in a volume of $625 \mathrm{ml}$ over 24 hours. Neither those taking streptokinase nor the controls were given anticoagulant treatment unless this became clinically indicated by thromboembolic events. No corticosteroid was given during the streptokinase infusion unless it was required to control pyrexia or skin reaction. The management of both groups was similar as regards the speed of mobilisation and length of stay in hospital.

Investigations-Conventional 12-lead ECGs were recorded on admission and then daily. Blood for SGOT measurement was drawn on entry to the trial and at 12,18 , and 24 hours and for $\mathrm{LDH}$ at entry and daily for 10 days. Fibrin degradation products (FDP) and thrombin time were estimated in the streptokinase group at entry and at 4,24 , and 48 hours. The FDP of all patients was measured in a single laboratory at one of the centres (JEM).

Necropsies were performed whenever possible in patients dying in hospital. The hearts were preserved with minimal dissection for later examination by the pathologist to the trial (CLB).

Follow-up-Patients were reassessed by means of clinical examination, chest $x$-ray examination, and ECG six weeks and six months after infarction.

\section{Results}

Sixty-one of the 600 patients admitted to the trial were excluded from the analysis because of failure to show recent myocardial infarction; four others were excluded because they departed from the protocol. Thus 595 patients ( 526 men and 69 women) were left for analysis. The numbers of patients contributed by the five centres for the final analysis are shown in table III. Although the numbers contributed by different centres varied widely all centres adhered to rigid inclusion and exclusion criteria during the study. Furthermore, patients were allocated to the streptokinase or control group according to a blind randomised code. There were 302 patients taking streptokinase and 293 controls. Prognostic subgroup A contained 234 on streptokinase and 227 controls, subgroup B 63 on streptokinase and 62 controls, and subgroup $C$ five on streptokinase and four controls.

A detailed assessment of the comparability of the streptokinase and control groups as a whole and by subgroup is shown in table IV. There were significantly more controls with a history of angina. Otherwise, there were no major differences in sex, age, previous infarction, initial systolic blood pressure, and interval between infarct and admission (start of streptokinase treatment in the treated group).

TABLE III-Numbers of treated and control patients with proved infarction contributed by the five participating centres

\begin{tabular}{|c|c|c|c|c|c|c|}
\hline Centre & 1 & 2 & 3 & 4 & 5 & Total \\
\hline $\begin{array}{l}\text { No on streptokinase } \\
\text { No of controls }\end{array}$ & $\begin{array}{l}97 \\
94\end{array}$ & $\begin{array}{l}39 \\
40\end{array}$ & $\begin{array}{l}30 \\
30\end{array}$ & $\begin{array}{l}46 \\
45\end{array}$ & $\begin{array}{l}90 \\
84\end{array}$ & $\begin{array}{l}302 \\
293\end{array}$ \\
\hline Total .. & 191 & 79 & 60 & 91 & 174 & 595 \\
\hline
\end{tabular}


TABLE IV-Comparability of groups on admission to trial

\begin{tabular}{|c|c|c|c|c|c|c|c|c|c|c|c|c|}
\hline & \multicolumn{3}{|c|}{ All groups } & \multicolumn{3}{|c|}{ Prognostic group 1} & \multicolumn{3}{|c|}{ Prognostic group 2} & \multicolumn{3}{|c|}{ Prognostic group 3} \\
\hline & $\begin{array}{l}\text { Strepto- } \\
\text { kinase } \\
\text { group }\end{array}$ & Controls & $\begin{array}{l}\text { Signifi- } \\
\text { cance } \\
\text { (P) }\end{array}$ & $\begin{array}{l}\text { Strepto- } \\
\text { kinase } \\
\text { group }\end{array}$ & Controls & $\begin{array}{l}\text { Signifi- } \\
\text { cance } \\
\text { (P) }\end{array}$ & $\begin{array}{l}\text { Strepto- } \\
\text { kinase } \\
\text { group }\end{array}$ & Controls & $\begin{array}{l}\text { Signifi- } \\
\text { cance } \\
\text { (P) }\end{array}$ & $\begin{array}{l}\text { Strepto- } \\
\text { kinase } \\
\text { group }\end{array}$ & Controls & $\begin{array}{c}\text { Signifi- } \\
\text { cance } \\
(\mathrm{P})\end{array}$ \\
\hline 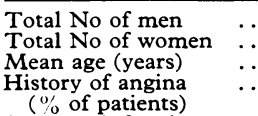 & $\begin{array}{l}272 \\
30 \\
55 \cdot 9 \\
45 \cdot 0\end{array}$ & $\begin{array}{l}254 \\
39 \\
57 \cdot 1 \\
54 \cdot 3\end{array}$ & $\begin{array}{c}\text { NS } \\
\text { NS } \\
<0.025\end{array}$ & $\begin{array}{c}214 \\
20 \\
54 \cdot 5 \\
45 \cdot 3\end{array}$ & $\begin{array}{l}196 \\
31 \\
56 \cdot 1 \\
56 \cdot 8\end{array}$ & $\begin{array}{l}<0.1 \\
<0.1 \\
<0.15 \\
<0.025\end{array}$ & $\begin{array}{l}53 \\
10 \\
60 \cdot 1 \\
\mathbf{4 4} \cdot 4\end{array}$ & $\begin{array}{c}54 \\
8 \\
60 \cdot 6 \\
46 \cdot 8\end{array}$ & $\begin{array}{l}\text { NS } \\
\text { NS } \\
\text { NS }\end{array}$ & $\begin{array}{c}5 \\
68 \cdot 6 \\
25 \cdot 0\end{array}$ & $\begin{array}{c}4 \\
60 \cdot 0 \\
40 \cdot 0\end{array}$ & $\begin{array}{l}\text { NS } \\
\text { NS } \\
\text { NS }\end{array}$ \\
\hline $\begin{array}{l}\text { Previous infarction } \\
\text { (\% of patients) }\end{array}$ & $19 \cdot 2$ & $18 \cdot 4$ & NS & $17 \cdot 9$ & $18 \cdot 1$ & NS & $23 \cdot 8$ & $21 \cdot 0$ & NS & $20 \cdot 0$ & nil & NS \\
\hline $\begin{array}{l}\text { Infarct to admission } \\
\text { (hours) }\end{array}$ & 6.9 & $7 \cdot 3$ & NS & 6.5 & $7 \cdot 6$ & NS & $6 \cdot 8$ & $7 \cdot 4$ & NS & $9 \cdot 0$ & $4 \cdot 6$ & NS \\
\hline $\begin{array}{l}\text { Systolic blood pressure } \\
\text { on admission ( } \mathrm{mm} \mathrm{Hg} \text { ) }\end{array}$ & $136 \cdot 4$ & $138 \cdot 5$ & NS & $146 \cdot 5$ & $149 \cdot 7$ & NS & $104 \cdot 8$ & $103 \cdot 4$ & NS & $59 \cdot 0$ & $50 \cdot 0$ & NS \\
\hline
\end{tabular}

Apart from test used for comparing groups in time from admission to infarct, tests based on the assumption of a normal distribution were used. For testing the comparability Apart from test used for comparing groups in time from admission to
in time from infarct to admission a Mann-Whitney U test was used.

Weights and heights were recorded in 183 patients on streptokinase and 189 controls. The mean height was $171 \mathrm{~cm}$ in each group and the mean weight less ideal weight $8.2 \mathrm{~kg}$ in those on streptokinase and $8.4 \mathrm{~kg}$ in the controls. The mean stay in hospital was 13.6 days in the streptokinase group and 13.9 days in the control group.

A further breakdown of the time from infarct to admission is given in table V. This confirms that there were no major differences in the time from infarct to admission between either the streptokinase or control group or the various prognostic subgroups. In all groups $25 \%$ of patients were admitted within three hours, $50 \%$ within five hours, and $75 \%$ within 12 hours.

All differences between the streptokinase and control groups tended to favour the streptokinase group slightly.

Mortality-The inpatient crude death rate in the streptokinase (38 deaths) and control groups (40 deaths) was similar (table VI). The death rates relative to the time of infarction and the cumulative death rates at seven days, six weeks, and six months are shown in table VII. Again no significant difference was evident, although that most nearly approaching significance was the difference between the two groups at 12 to 24 hours after the onset of symptoms $(P=0.07)$.

TABLE V-Quartiles of distribution of times from infarct to admission (hours)

\begin{tabular}{|c|c|c|c|c|c|c|}
\hline & \multicolumn{3}{|c|}{ Streptokinase group } & \multicolumn{3}{|c|}{ Controls } \\
\hline & Lower & Median & Upper & Lower & Median & Upper \\
\hline $\begin{array}{ll}\text { Prognostic group } 1 & \ldots \\
\text { Prognostic group } 2 & \ldots \\
\text { Prognostic group } 3 & \ldots\end{array}$ & $\begin{array}{l}3 \\
3 \\
3\end{array}$ & $\begin{array}{l}5 \\
4 \\
5\end{array}$ & $\begin{array}{r}10 \\
9 \\
6\end{array}$ & $\begin{array}{l}3 \\
3 \\
1\end{array}$ & $\begin{array}{l}5 \\
4 \\
2\end{array}$ & $\begin{array}{l}11 \\
12 \\
12\end{array}$ \\
\hline All groups ... & 3 & 5 & 10 & 3 & 5 & 12 \\
\hline
\end{tabular}

TABLE VI-Inpatient mortality (\%) in streptokinase and control groups. Actual numbers of inpatient deaths are given in parentheses

\begin{tabular}{|c|c|c|c|}
\hline & Streptokinase group & Controls & Total \\
\hline \multicolumn{4}{|c|}{ Centres } \\
\hline $\begin{array}{l}1 \\
2 \\
3 \\
4 \\
5\end{array}$ & $\begin{aligned} 12 \cdot 4(12) \\
7 \cdot 7(3) \\
20 \cdot 0(6) \\
8 \cdot 7(4) \\
14 \cdot 4(13)\end{aligned}$ & $\begin{array}{c}9 \cdot 6(9) \\
15 \cdot 0(6) \\
13.3(4) \\
15.6(7) \\
16.7(14)\end{array}$ & $\begin{array}{l}11.0(21) \\
11.4(9) \\
16.7(10) \\
12.1(11) \\
15.5(27)\end{array}$ \\
\hline \multicolumn{4}{|c|}{ Prognostic groups } \\
\hline $\begin{array}{l}\mathbf{A} \\
\mathbf{B} \\
\mathbf{C}\end{array}$ & $\begin{aligned} 9 \cdot 0(21) \\
23 \cdot 8(15) \\
40 \cdot 0(2)\end{aligned}$ & $\begin{array}{r}9.7(22) \\
22.6(14) \\
100.0(4)\end{array}$ & $\begin{array}{r}9 \cdot 3(43) \\
23 \cdot 2(29) \\
66 \cdot 7(6)\end{array}$ \\
\hline Total & $12 \cdot 6(38)$ & $13 \cdot 7(40)$ & $13 \cdot 1(78)$ \\
\hline
\end{tabular}

TABLE VIII-Mortality in relation to site of infarct in streptokinase and control groups. Actual numbers of deaths are given in parentheses

\begin{tabular}{|c|c|c|c|c|}
\hline \multirow{2}{*}{\multicolumn{2}{|c|}{ Site of infarct }} & \multirow[b]{2}{*}{$\begin{array}{l}\text { Total No of } \\
\text { patients }\end{array}$} & \multicolumn{2}{|c|}{ Mortality (\%) } \\
\hline & & & $\begin{array}{l}\text { Streptokinase } \\
\text { group }\end{array}$ & Controls \\
\hline $\begin{array}{l}\text { Anterior, anterolateral and } \\
\text { lateral } \\
\text { Interior and inferiolateral } \\
\text { Anterior and inferior .. } \\
\text { ECG non-localising } \\
\text { (enzymes positive) .. }\end{array}$ & $\begin{array}{l}\cdots \\
\cdots \\
\ldots\end{array}$ & $\begin{array}{r}282 \\
258 \\
16 \\
39\end{array}$ & $\begin{array}{l}21(31) \\
7(9) \\
43(3) \\
25(5)\end{array}$ & $\begin{array}{l}25(33) \\
8(11) \\
33(3) \\
26(5)\end{array}$ \\
\hline
\end{tabular}

TABLE IX-Incidence of cardiac failure, reinfarction, and arrhythmias ( $\%$ of patients) in streptokinase and control groups

\begin{tabular}{|c|c|c|c|}
\hline & $\begin{array}{l}\text { Streptokinase } \\
\text { group }\end{array}$ & Controls & $\begin{array}{c}\text { Significance } \\
(\mathrm{P})\end{array}$ \\
\hline $\begin{array}{l}\text { Cardiac failure: } \\
\text { On admission } \\
\text { From } 24 \text { hours to discharge }\end{array}$ & $23 \cdot 8$ & 21.8 & NS \\
\hline $\begin{array}{ccc}\text { (or death) } & \cdots & \cdots\end{array}$ & $13 \cdot 5$ & $14 \cdot 0$ & NS \\
\hline $\begin{array}{l}\text { Reinfarction: } \\
\text { Before discharge (or death) }\end{array}$ & $3 \cdot 6$ & $4 \cdot 1$ & NS \\
\hline $\begin{array}{l}\text { All arrhythmias } \\
\text { Major arrhythmias* } \because\end{array}$ & $\begin{array}{l}53 \\
23\end{array}$ & $\begin{array}{l}59 \\
30\end{array}$ & $\begin{array}{c}\text { NS } \\
<0.05\end{array}$ \\
\hline
\end{tabular}

*See text.

There was no relationship between mortality and site of infarction (table VIII).

Incidence of cardiac failure, reinfarction, and arrhythmias-Cardiac failure was diagnosed on conventional clinical grounds, while the same diagnostic criteria were applied to reinfarction as were used for the original infarct. ${ }^{9}$ ECG tracings were used to define the nature and incidence of arrhythmias and other disorders of conduction. We thought that in the interest of brevity these could be grouped under a single heading of "major" arrhythmias, which included atrial fibrillation, supraventricular tachycardia, left or right bundle-branch block, heart block (grades 1,2, and 3), ventricular tachycardia, and fibrillation and asystole. The incidences of cardiac failure, reinfarction, and major arrhythmias is shown in table IX. The control group showed a significantly greater incidence of major arrhythmias.

Enzyme levels-The enzyme peaks were of comparable magnitude and occurred at much the same interval after infarction in both groups (tables X and XI). SGOT levels were measured only during the first 24 hours after admission to the study, while LDH was estimated daily for 10 days. As expected the peak levels were significantly higher in those patients who died.

TABLE VII-Overall mortality (\%) at intervals after infarction and overall rate at six weeks' and six months' follow-up

\begin{tabular}{|c|c|c|c|c|c|c|c|c|c|}
\hline & $<12 \mathrm{~h}$ & $-24 h$ & $-48 h$ & -7 days & $\begin{array}{c}\text { Total } \\
\text { at } 7 \text { days }\end{array}$ & -6 weeks & $\begin{array}{c}\text { Total } \\
\text { at } 6 \text { weeks }\end{array}$ & -6 months & $\begin{array}{l}\text { Total } \\
\text { at } 6 \text { months }\end{array}$ \\
\hline $\begin{array}{l}\text { Streptokinase group } \\
\text { Controls } \ldots\end{array}$ & $\begin{array}{l}2 \cdot 7 \\
1 \cdot 8\end{array}$ & $\begin{array}{l}1 \cdot 0 \\
3 \cdot 1\end{array}$ & $\begin{array}{l}2 \cdot 1 \\
1.8\end{array}$ & $\begin{array}{l}5 \cdot 6 \\
4 \cdot 7\end{array}$ & $\begin{array}{l}10 \cdot 9 \\
10.9\end{array}$ & $\begin{array}{l}3 \cdot 7 \\
4 \cdot 6\end{array}$ & $\begin{array}{l}14 \cdot 2 \\
15 \cdot 0\end{array}$ & $\begin{array}{l}1 \cdot 9 \\
3 \cdot 2\end{array}$ & $\begin{array}{l}15.9 \\
17.8\end{array}$ \\
\hline
\end{tabular}


TABLE X-Peak SGOT levels in streptokinase and control groups

\begin{tabular}{|c|c|c|c|c|c|c|}
\hline \multirow{2}{*}{\multicolumn{3}{|c|}{ SGOT levels }} & \multicolumn{2}{|c|}{ Streptokinase group } & \multicolumn{2}{|c|}{ Controls } \\
\hline & & & $\begin{array}{c}\text { No of } \\
\text { patients }\end{array}$ & $\underset{(I U / 1)}{\text { Mean peak }}$ & $\begin{array}{c}\text { No of } \\
\text { patients }\end{array}$ & $\underset{\text { (IU/1) }}{\text { Mean peak }}$ \\
\hline $\begin{array}{l}\text { At admission } \\
12 \text { hours } \\
18 \text { hours } \\
24 \text { hours }\end{array}$ & $\begin{array}{l}\ldots \\
\cdots \\
\cdots\end{array}$ & $\begin{array}{l}. \\
\because \\
\because\end{array}$ & $\begin{array}{r}23 \\
82 \\
85 \\
101\end{array}$ & $\begin{array}{l}156 \cdot 47 \\
299 \cdot 30 \\
319 \cdot 58 \\
317 \cdot 18\end{array}$ & $\begin{array}{r}28 \\
43 \\
83 \\
122\end{array}$ & $\begin{array}{l}179 \cdot 10 \\
201 \cdot 62 \\
231 \cdot 15 \\
287 \cdot 63\end{array}$ \\
\hline \multicolumn{3}{|c|}{ Total recorded } & 291 & $300 \cdot 14$ & 276 & $246 \cdot 23$ \\
\hline \multicolumn{2}{|c|}{$\begin{array}{l}\text { Number dead } . . \\
\text { Number alive } . .\end{array}$} & 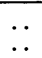 & $\begin{array}{r}44 \\
247\end{array}$ & $\begin{array}{l}439 \cdot 88 \\
275 \cdot 25\end{array}$ & $\begin{array}{r}41 \\
235\end{array}$ & $\begin{array}{l}335 \cdot 00 \\
230 \cdot 75\end{array}$ \\
\hline \multicolumn{3}{|c|}{ Not recorded } & 11 & & 17 & \\
\hline
\end{tabular}

TABLE XI-Peak LDH levels in streptokinase and control groups

\begin{tabular}{|c|c|c|c|c|c|c|}
\hline \multirow{2}{*}{\multicolumn{3}{|c|}{ LDH levels }} & \multicolumn{2}{|c|}{ Streptokinose group } & \multicolumn{2}{|c|}{ Control } \\
\hline & & & $\begin{array}{c}\text { No of } \\
\text { patients }\end{array}$ & $\begin{array}{c}\text { Mean peak } \\
(\mathrm{IU} / \mathrm{l})\end{array}$ & $\begin{array}{c}\text { No of } \\
\text { patients }\end{array}$ & $\begin{array}{l}\text { Mean peak } \\
\text { (IU/1) }\end{array}$ \\
\hline $\begin{array}{l}\text { At admission } \\
24 \text { hours } \\
48 \text { hours } \\
3 \text { days } . . \\
4 \text { days } . \\
5 \text { days } . . \\
6 \text { days } . \\
7 \text { days } . . \\
8 \text { days } . . \\
9 \text { days } . \\
10 \text { days } .\end{array}$ & $\begin{array}{l}\cdots \\
\cdots \\
\cdots \\
\cdots \\
\cdots \\
\cdots \\
\cdots \\
\cdots \\
\cdots\end{array}$ & $\begin{array}{l}\ldots \\
\ldots \\
\ldots \\
\ldots \\
\cdots \\
\cdots \\
\cdots \\
\cdots\end{array}$ & $\begin{array}{r}16 \\
158 \\
68 \\
28 \\
6 \\
1 \\
2 \\
1\end{array}$ & $\begin{array}{r}601.56 \\
1425 \cdot 84 \\
1333.61 \\
1201.39 \\
742.50 \\
580.00 \\
470.00 \\
295.00\end{array}$ & $\begin{array}{r}24 \\
113 \\
99 \\
19 \\
9 \\
2 \\
1 \\
3 \\
2\end{array}$ & $\begin{array}{r}661 \cdot 16 \\
1301 \cdot 42 \\
1566 \cdot 81 \\
1255 \cdot 00 \\
622 \cdot 77 \\
947 \cdot 50 \\
860 \cdot 00 \\
370 \cdot 00 \\
515 \cdot 00\end{array}$ \\
\hline \multicolumn{3}{|c|}{ Total recorded } & 281 & $1306 \cdot 70$ & 272 & 1293.45 \\
\hline \multicolumn{2}{|c|}{$\begin{array}{l}\text { Number dead .. } \\
\text { Number alive } \ldots\end{array}$} & $\because$. & $\begin{array}{r}40 \\
241\end{array}$ & $\begin{array}{l}1806 \cdot 40 \\
1223 \cdot 76\end{array}$ & $\begin{array}{r}41 \\
231\end{array}$ & $\begin{array}{l}1554 \cdot 87 \\
1247 \cdot 05\end{array}$ \\
\hline \multicolumn{3}{|c|}{ Not recorded } & 21 & & 21 & \\
\hline
\end{tabular}

TABLE XII-Fibrinolytic degradation products at four hours in streptokinase and control groups

\begin{tabular}{|c|c|c|c|c|}
\hline \multirow{2}{*}{ FDP titre } & \multicolumn{2}{|c|}{ Streptokinase group } & \multicolumn{2}{|c|}{ Controls } \\
\hline & $\underset{\text { patients }}{\text { All }}$ & $\begin{array}{l}\text { Patients } \\
\text { who died }\end{array}$ & $\underset{\text { patients }}{\text { All }}$ & $\begin{array}{l}\text { Patients } \\
\text { who died }\end{array}$ \\
\hline $\begin{array}{l}1 / 2 \\
1 / 4 \\
1 / 8\end{array}$ & $\begin{array}{r}18 \\
11 \\
6\end{array}$ & 2 & $\begin{array}{r}155 \\
37 \\
7\end{array}$ & $\begin{array}{r}21 \\
8 \\
1\end{array}$ \\
\hline $\begin{array}{l}1 / 16 \\
1 / 32 \\
1 / 64\end{array}$ & $\begin{array}{r}5 \\
10 \\
6\end{array}$ & 1 & $\begin{array}{l}2 \\
1\end{array}$ & 1 \\
\hline $\begin{array}{l}1 / 128 \\
1 / 256 \\
1 / 512\end{array}$ & $\begin{array}{l}11 \\
22 \\
30\end{array}$ & $\begin{array}{r}10 \\
6\end{array}$ & 1 & 1 \\
\hline $\begin{array}{l}1 / 1024 \\
1 / 2048 \\
1 / 4096\end{array}$ & $\begin{array}{l}52 \\
18 \\
19\end{array}$ & $\begin{array}{l}9 \\
1 \\
1\end{array}$ & 3 & \\
\hline $1 / 8192$ & 9 & 1 & & \\
\hline $\begin{array}{l}\text { Total recorded } \\
\text { Not recorded }\end{array}$ & $\begin{array}{r}217 \\
85\end{array}$ & $\begin{array}{l}33 \\
15\end{array}$ & $\begin{array}{r}206 \\
87\end{array}$ & $\begin{array}{l}32 \\
20\end{array}$ \\
\hline Total & 302 & 48 & 293 & 52 \\
\hline
\end{tabular}

Fever-Inspection of the patients' temperature records showed no significant difference in pattern between the two groups. Febrile reactions attributed to streptokinase were few, but 13 patients were given corticosteroids, and five of these showed fever disproportionate to the infarct. Steroids were also given to six patients in the control group for conditions unrelated to the infarction.

Fibrinolytic activity-As a measure of the effectiveness of streptokinase treatment fibrinolytic activity was assessed by measuring the level of FDP in the serum by the tanned red cell haemagglutinationinhibition immunoassay. ${ }^{12}$ The FDP levels at four hours in the treated and control groups are given in table XII. A titre of less than 1/8 may be regarded as normal by this method. A significantly raised FDP concentration was found in 188 out of 217 cases $(87 \%$ ) in the treated group, with titres of $1 / 256$ or more being seen in 150 cases $(69 \%)$. Thrombin times (table XIII) closely paralleled the FDP levels. In practice, these results were seldom available before the end of streptokinase infusion and did not therefore influence dosage or management.

Haemorrhagic complications-The incidence of bruising, epistaxis, haematuria and gastrointestinal bleeding is shown in table XIV. In the main these episodes were not severe, but in six patients in the streptokinase group the haemorrhage was severe enough to necessitate stopping treatment and reversing the fibrinolysis. In one patient on streptokinase and one control a gastrointestinal bleed may have contributed to death. Neither patient was receiving anticoagulant treatment. The haemorrhages in the streptokinase group were not predictable by excessively prolonged thrombin times.

Thromboembolic complications-Clinically diagnosed venous thrombosis, pulmonary embolism, and systemic embolism occurred more often in the control group. The incidence of stroke was similar in both groups (table XV).

Pathology-Fifty-three hearts were available for pathological examination, 27 from the streptokinase group and 26 from the control group. Two hearts from the streptokinase group were excluded from the study when it was found that no streptokinase had been administered before death, and two control hearts were excluded because of

TABLE XIII-Thrombin times at admission and at four hours in streptokinase and control groups

\begin{tabular}{c|c|c|c|c|c|c|c|c}
\hline $\begin{array}{c}\text { Ratio of } \\
\text { thrombin time } \\
\text { at 4 h to } \\
\text { admission } \\
\text { value*: }\end{array}$ & 0 & 1 & 2 & 3 & 4 & 5 & $\begin{array}{c}\text { Not } \\
\text { recorded }\end{array}$ & Total \\
\hline $\begin{array}{c}\text { No of patients: } \\
\text { Streptokinase } \\
\text { group }\end{array}$ & 10 & 94 & 83 & 36 & 17 & 21 & 41 & 302 \\
Controls & 73 & 158 & 73 & & & & & \\
\hline
\end{tabular}

* Lower limit of interval.

The desired thrombin time range is two to four times the control value (admission). The desired thrombin time range is two to four times the control value

TABLE XIV-Haemorrhagic complications in hospital in streptokinase and control groups. Figures in parentheses indicate number of patients in whom streptokinase treatment was stopped

\begin{tabular}{c|c|c|c|c|c}
\hline & Bruising & Epistaxis & Haematuria & $\begin{array}{c}\text { Gastrointestinal } \\
\text { bleeding }\end{array}$ & Other \\
\hline $\begin{array}{c}\text { No in streptokinase } \\
\text { group .. }\end{array}$ & 26 & $6(1)$ & $5(2)$ & $\underset{2}{4}(3)$ & 1 \\
$\begin{array}{c}\text { No of controls } \\
.\end{array}$ & 1 & 1 & & 1
\end{tabular}

Figures indicate numbers of patients. Brackets show those in whom SK therapy was terminated.

TABLE XV-Thromboembolic complications in hospital in streptokinase and control groups

\begin{tabular}{|c|c|c|c|c|c|}
\hline & & $\begin{array}{l}\text { Venous } \\
\text { thrombosis }\end{array}$ & $\begin{array}{l}\text { Pulmonary } \\
\text { embolism }\end{array}$ & $\begin{array}{c}\text { System } \\
\text { embolism }\end{array}$ & Stroke \\
\hline $\begin{array}{l}\text { No on streptokinase } \\
\text { group } \\
\text { No of controls ... }\end{array}$ & $\because$ & $\begin{array}{r}8 \\
17 \\
\end{array}$ & $\begin{array}{r}5 \\
13 \\
\end{array}$ & 3 & $\begin{array}{l}5 \\
5\end{array}$ \\
\hline Significance $(\mathbf{P})$ & $\ldots$ & $<0 \cdot 1$ & $<0 \cdot 1$ & & \\
\hline
\end{tabular}

TABLE XVI-Pathological findings in 49 hearts from patients in streptokinase and control groups

\begin{tabular}{|c|c|c|c|}
\hline & & $\begin{array}{l}\text { Streptokinase } \\
\text { group }\end{array}$ & Controls \\
\hline $\begin{array}{l}\text { No of hearts examined } \\
\text { Nature of occluding lesion: } \\
\text { Thrombus ... } \\
\text { Haemorrhage in plaque } \\
\text { Stenosis only } \\
\text { Previous occlusion ... } \\
\text { Endocardial thrombus.. } \\
\text { Myocardial tears } \\
\text { Evidence of previous ischaem } \\
\text { Extension of infarct ... } \\
\text { Haemorrhagic infarcts.. }\end{array}$ & $\begin{array}{l} \\
\ldots \\
\cdots \\
\cdots \\
\cdots \\
\because \\
\therefore\end{array}$ & $\begin{array}{r}25 \\
11 \\
3 \\
3 \\
8 \\
11 \\
5 \\
11 \\
2 \\
3\end{array}$ & $\begin{array}{r}10 \\
6 \\
3 \\
6 \\
10 \\
4 \\
12 \\
3\end{array}$ \\
\hline
\end{tabular}


extensive dissection before examination by the trial pathologist. At the time of examination the group to which each heart belonged was not known. The findings in the remaining 49 hearts are summarised in table XVI. Full information on macroscopic examination and microscopy has been published elsewhere. ${ }^{13}$

\section{Discussion}

The rationale of streptokinase treatment in acute myocardial infarction has never rested on the sanguine expectation that lysis of newly formed thrombus would protect the threatened myocardium from necrosis. It seemed possible, however, that the size of the infarct might be reduced by preventing extending thrombosis in the affected or neighbouring arteries or in small vessels at the periphery of the infarct. If this were so a fall in mortality or in early complications might be apparent. The results of our own and other studies conducted entirely in coronary care units have failed to confirm this hypothesis, however. Details of the earlier major trials of streptokinase in acute infarction are summarised in table I together with those of our study. The dose and duration of streptokinase treatment are broadly comparable and in all trials the treatment was started within 24 hours of the onset of symptoms. Like ours, patients in the Italian and Australian studies were all treated in coronary care units. Our trial differed chiefly in that anticoagulant treatment was given to neither those receiving streptokinase nor controls unless indicated by the development of thromboembolic complications.

On the basis of the simple prognostic index only nine patients fell into subgroup C. Admission of patients to the trial at the five participating centres was neither universal nor consecutive but was governed by administrative and staffing considerations. There were understandable problems in entering a patient whose clinical condition was already absorbing the efforts of the staff in supportive or resuscitative measures. The small number of patients in this group precludes meaningful analysis and leaves open the question whether such patients might benefit from streptokinase. Once admitted to the trial, however, allocation of the patient to either the streptokinase or control group was according to strict blind random chart.

No significant difference in overall mortality emerges from analysis of prognostic subgroups $A$ and $B$, but there was a wide and unexplained variation between the mortality rates at different centres (table VI). This has also been seen in other studies. ${ }^{5}$ Two patients in the streptokinase and three in the control group died within six hours of infarction.

The largest difference in the hospital death rates between those on streptokinase and controls occurred 12-24 hours after infarction. Though fibrinolytic activity should be maximal at this time the difference was still not significant $(P=0.07)$, and there are no data to suggest that this slightly favourable trend would have continued had anticoagulants been used after the streptokinase infusion. The analysis shows no evidence that any particular feature such as age, early treatment, or site of infarct influenced the outcome in the two groups. Nor does a comparison of the peak values of SGOT or LDH suggest that streptokinase limits the extent of myocardial necrosis. It was not unexpected that the mean peaks in the 85 patients who died exceeded those of the survivors, for it is now established that the magnitude of the enzyme rise reflects the size of the infarct.

The incidence of cardiac failure and reinfarction in hospital was similar in the two groups. Although the incidence of major arrhythmias was less in the streptokinase group this had no bearing on the ultimate mortality.

Though the incidence of haemorrhagic manifestations in the streptokinase group cannot be ignored it was not prohibitive, being a possible contributory cause of death in only one patient. Allergic reactions to streptokinase did not constitute a problem despite the absence of routine corticosteroid cover. The difference in thromboembolic complications in the two groups was favourable to streptokinase and may reasonably be attributed to the drug's thrombolytic action at a time when immobility and reduced cardiac output were conducive to stasis.

Pathological examination of hearts showed that the only difference between the groups that might be significant was the finding of haemorrhagic infarcts in three patients given streptokinase, a change that has been commented on. ${ }^{14}$ The rather high incidence of myocardial rupture in both groups was probably related to external cardiac massage during attempted resuscitation.

Our trial, like the Italian and Australian ones, has failed to provide support for the routine use of streptokinase in acute myocardial infarction. Its prophylactic value in crescendo angina has yet to be assessed by a controlled study.

We thank Professor A S Douglas of Aberdeen for advice on the design of the study; $\mathrm{Mr}$ I Clarke, who performed the statistical analysis; Mrs P Blackshaw of Manchester, who performed the FDP estimations under the direction of Dr J E MacIver; and Mrs P Freeman and Mrs J P Germain for the section of the hearts under the direction of Dr C L Berry. We also thank all other staff at the hospitals concerned who helped us to complete this study. Hoechst Pharmaceuticals supplied the Streptase and supported the study financially.

\section{References}

${ }^{1}$ Johnson, A J, and McCarty, W R, fournal of Clinical Investigation, 1959, 38, 1627.

2 Fletcher, A P, et al, fournal of Clinical Investigation, 1959, 38, 111.

${ }^{3}$ Schmutzler, R, et al, German Medical Monthly, 1966, 11, 308 (translated from Deutsche Medizinische Wochenschrift, 1966, 91, 581).

4 Praetorius, F, et al, Sixth World Congress of Cardiology, Abstracts. London, British Medical Association, 1970.

${ }^{5}$ European Working Party, British Medical fournal, 1971, 3, 325.

${ }^{6}$ Dioguardi, N, et al, Lancet, 1971, 2, 891.

7 Bett, J H N, et al, Lancet, 1973, 1, 58.

${ }^{8}$ Bass, N, Postgraduate Medical fournal, 1973, 49, suppl No 5, p 127.

9 World Health Organisation, Hypertension and Coronary Heart Disease: Classification and Criteria for Epidemiological Studies, Technical Report Series No 168. Geneva, WHO, 1959.

10 Armitage, P, Sequential Medical Trials. London, Blackwell Scientific, 1975.

11 Norris, R M, et al, Lancet, 1969, 1, 274.

12 Merskey, C, Lalazari, P, and Johnson, A J, Proceedings of the Society for Experimental Biology and Medicine, 1969, 131, 871.

13 Berry, C L, fournal of Clinical Pathology, 1975, 28, 352.

14 Schachenmayr, W, and Haferkamp, O, Deutsche Medizinische Wochenschrift, 1972, 97, 1172. 